\title{
Genetic Control of Inflammatory Gene Induction and NF- $k$ B-like Transcription Factor Activation in Response to an Atherogenic Diet in Mice
}

\author{
Feng Liao, * Ali Andalibi, * Frederick C. deBeer, ${ }^{*}$ Alan M. Fogelman, ${ }^{\star}$ and Aldons J. Lusis *s \\ * Department of Medicine, Division of Cardiology, University of California Los Angeles (UCLA) School of Medicine, \\ Los Angeles, California 90024-1679; ' ${ }^{\ddagger}$ Department of Medicine, Division of Rheumatology, University of Kentucky \\ College of Medicine, Lexington, Kentucky 40536; and ${ }^{\S}$ Department of Microbiology and Molecular Genetics and \\ Molecular Biology Institute, UCLA, Los Angeles, California 90024
}

\begin{abstract}
A high fat, high cholesterol "atherogenic" diet induced considerably greater hepatic levels of conjugated dienes and expression of several inflammatory and oxidative stress responsive genes ( $\mathrm{JE}$, the mouse homologue of monocyte chemotactic protein-1, colony-stimulating factors, heme oxygenase, and members of the serum amyloid $A$ family) in fatty streak susceptible C57BL/6 mice compared to fatty streak resistant C3H/ HeJ mice. Since serum amyloid A proteins bind exclusively to HDL and influence the properties of HDL, serum amyloid $A$ expression may contribute to the decrease in HDL levels seen in the susceptible strains. Induction of a similar set of genes was observed upon injection of minimally oxidized low density lipoprotein. The transcription factor NF- $\kappa$ B is known to be activated by oxidative stress and is involved in the transcriptional regulation of several of these genes. On the atherogenic diet the susceptible C57BL/6 mice exhibited significant NF-кB-like activation whereas the resistant $\mathrm{C} 3 \mathrm{H} / \mathrm{HeJ}$ mice exhibited little or no activation. These results are consistent with the hypothesis that the atherogenic diet resulted in the accumulation of oxidized lipids in certain tissues (e.g., liver and arteries) and the resulting inflammatory response to this oxidative stress was genetically determined. (J. Clin. Invest. 1993. 91:25722579.) Key words: early response genes • heme oxygenase • serum amyloid $A \cdot$ colony-stimulating factors $-N F-\kappa B$-like factor(s)
\end{abstract}

\section{Introduction}

There is accumulating evidence that oxidative modifications of LDL contribute to early atherogenesis. Oxidative or other modifications of LDL are necessary to produce "foam cells" that are characteristic of fatty streaks. Recently, LDL oxidized by various procedures has been shown to stimulate vascular wall cells to express adhesion molecule(s), chemotactic factors, growth factors, to inhibit vasodilation, and to be cytotoxic (1$5)$. Several lines of evidence now point to the key role of inflammatory processes in the pathogenesis of atherosclerosis (6-10). Immunohistochemical studies (11-13) and biochemical analy-

Address correspondence to Dr. Feng Liao, Department of Medicine, Division of Cardiology, University of California, Los Angeles School of Medicine, Los Angeles, CA 90024-1679.

Received for publication 2 October 1992 and in revised form 19 January 1993.

J. Clin. Invest.

(C) The American Society for Clinical Investigation, Inc. $0021-9738 / 93 / 06 / 2572 / 08 \quad \$ 2.00$

Volume 91, June 1993, 2572-2579 sis of the artery wall extracts (12) indicate that oxidized LDL species are present in artery wall lesions. Moreover, autoantibodies to oxidized LDL occur in both human and animal sera $(13,14)$. Evidence linking oxidized LDL to atherosclerosis remains indirect but is supported by numerous studies showing that treatment of animals with various antioxidants inhibits lesion development $(1,15)$.

This paper investigates the relationship between induction of inflammatory genes and lipid peroxidation in genetically defined strains of mice differing in susceptibility to early atherogenesis (aortic fatty streaks). Previously we demonstrated that administration of minimally oxidized LDL (MM-LDL) ${ }^{1}$ into the circulation of mice resulted in a rapid induction of macrophage colony stimulating factor (M-CSF) activity in the blood and mRNA for JE (the mouse homologue of monocyte chemotactic protein-1) in various tissues, including the liver (16). Moreover, the injection of MM-LDL significantly increased monocyte adhesion to the wall of the aorta (17). Gerrity and co-workers (18) have previously shown that swine fed a high fat diet exhibit a large increase in circulating M-CSF. We reasoned that if, indeed, accumulation of lipoprotein and subsequent lipid peroxidation in the artery wall is causal in early atherogenesis, induction of inflammatory genes elicited by feeding a high fat, high cholesterol "atherogenic" diet should differ in some aspect in fatty streak susceptible and resistant strains of mice. A limitation of studies with mice is the very small size of arteries, making biochemical analysis of lipids and gene expression difficult. Since the liver is known to accumulate lipids when mice consume an atherogenic diet, and since liver JE has been shown to be inducible by MM-LDL injection, this organ provides a model to test our hypothesis.

Our results demonstrate that an atherogenic diet challenge and injection of MM-LDL increase the expression of the similar set of inflammatory and oxidative stress responsive genes in the liver, including JE, KC, serum amyloid A (SAA), and heme oxygenase. Both also increase the activity of colony stimulating factors (CSF) in the circulation. Paralleling dietary induction of these genes was accumulation of tissue lipid peroxides and activation of NF- $\kappa$ B-like transcription factor(s). NF$\kappa \mathrm{B}$ is a transcription factor that, upon receiving the stimuli of reactive oxygen intermediates, translocates to the nucleus and induces transcription of various inflammatory genes (19), including JE and SAA (20, 21 ). Remarkably, there was a striking correlation among mouse strains between inflammatory gene induction and susceptibility to fatty streak development. Thus,

1. Abbreviations used in this paper: ALK, alkaline phosphatase; ALT, alanine aminotransferase; AST, aspartate aminotransferase; CSF, colony-stimulating factor; M-CSF, macrophage CSF; MM-LDL, minimally oxidized LDL. 
the atherogenesis susceptible strain C57BL/6 mice exhibited considerably greater induction of inflammatory genes and increase of NF- $\kappa$ B-like activity than the atherogenesis resistant strain $\mathrm{C} 3 \mathrm{H} / \mathrm{HeJ}$ mice, whereas strain $\mathrm{BALB} / \mathrm{c}$ mice were intermediate with respect to aortic lesion susceptibility and inflammatory gene induction. There was also a significant difference in the accumulation of conjugated dienes between the strains. Our results provide support for the concept that lipid peroxidation can trigger the expression of inflammatory genes likely to be involved in early atherogenesis. Furthermore, they suggest that genetic control of the processes affecting lipid peroxidation and inflammatory gene induction may determine the susceptibility of animals to the disease.

\section{Methods}

Mice. $\mathrm{C} 3 \mathrm{H} / \mathrm{HeJ}$ and $\mathrm{C} 3 \mathrm{H} / \mathrm{HeSN}$ mice were purchased from the Jackson Laboratory, Bar Harbor, ME. BALB/c mice were purchased from either the Jackson Laboratory or Harlan Sprague Dawley, Inc., Indianapolis, IN. C57BL/6 mice were purchased from either the Jackson Laboratory or B \& K Universal Inc., Fremont, CA. All of the mice were females, 3-6 mo old. The control diet was Purina chow (Ralston-Purina Co., St. Louis, MO) containing $4 \%$ fat. The atherogenic diet, obtained from Teklad, Madison, WI (TD 90221), contained 15.75\% fat, $1.25 \%$ cholesterol, and $0.5 \%$ sodium cholate.

Lipoproteins. Human LDL isolation and preparation of MM-LDL by cold storage and iron oxidation were performed as previously described $(2,16)$.

Serum CSF assay. Mouse bone marrow cell colony formation assay was used to determine the CSF activity in mouse sera as described in detail elsewhere (16).

RNA analysis. Tissues were collected, frozen in liquid nitrogen, and stored at $-70^{\circ} \mathrm{C}$. Total RNA was extracted using the acid guanidinium thiocyanate-phenol-choloroform method (22). RNA samples $(20 \mu \mathrm{g})$ were denatured and electrophoresed through a $1 \%$ formaldehyde agarose gel followed by blotting to nylon filters and ultraviolet cross-linking.

cDNA clones used for hybridization was obtained as following: murine JE (pJE) (23), KC (pKC) (24), and 18S ribosomal RNA (Rn18S) (25) were purchased from American Type Culture Collection, Rockville, MD; murine c-fos and human $\alpha$-tubulin were kindly provided, respectively, by Drs. R. Chiu and W. Salzer, UCLA; murine heme oxygenase (26) was kindly provided by Dr. S. Sakiyama, Chiba Cancer Center Research Institute, Japan; murine IL- $1 \alpha$ was clone pIL-

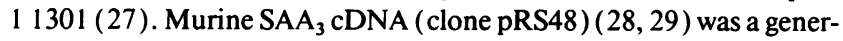
ous gift from Dr. B. Taylor, the Jackson Laboratory.

18-base long oligonucleotides specific for $\mathrm{SAA}_{1}, \mathrm{SAA}_{2}$, and $\mathrm{SAA}_{3}$ were used as reported previously (30). End labeling of the oligonucleotides and hybridization of blots were performed according to previously published methods ( 30 ) with modification. Before experiments, the specificity of these oligonucleotides under our conditions was confirmed by Northern analysis on the RNA extracted from different tissues of mice injected with LPS. Analysis of RNA for SAA was obtained using an $\mathrm{SAA}_{3}$ cDNA probe (which cross-hybridizes with $\mathrm{SAA}_{1}$ and $\mathrm{SAA}_{2}$ ) except where otherwise indicated.

Lipid extraction and measurement of conjugated dienes. The total lipids were extracted from the livers of mice immediately after killing following the method of Folch et al. (31). Conjugated dienes were measured by means of the second derivative ultraviolet absorption spectra of the lipids in hexene (32) and quantitated using soybean lipoxygenase oxidized linoleic acid as a standard.

Nuclear extracts and mobility shift assay. Livers were collected and stored in the same way as for RNA analysis. Nuclear extracts were made from tissues according to established protocols with minor modifications $(33,34)$. Briefly, $\sim 0.4 \mathrm{~g}$ of liver tissue was minced in cold PBS and the minced chunks were disrupted in buffer $A$ with $0.1 \%$
NP-40 using a Dounce homogenizer with a type B pestle. The crude nuclear pellets were then resuspended in buffer $C$. The nuclear extracts were then diluted with buffer D. Nuclear extracts were also prepared from cultured cells as described previously (34). Mobility shift assays were carried out according to a standard protocol using the NF- $\kappa B$ and SP-1 binding protein detection system (catalogue number 3382SA and 3382SB; Gibco/BRL, Gaithersburg, MD). Competitions were performed using a 50 -fold molar excess of unlabeled NF- $\kappa$ B-binding oligonucleotide. Since numerous transcription factors have been identified in the NF- $\kappa$ B family, this assay actually detects the activation of the sum of these transcription factors that recognize the consensus binding sequence.

Liver histology and serum enzyme assays. Mouse liver samples were either $(a)$ fixed in formalin, paraffin-embedded, and stained with hematoxylin and eosin, or $(b)$ frozen-sectioned and stained with oil red $O$. Serum enzyme assays for alkaline phosphatase, alanine aminotransferase, and aspartate aminotransferase were performed in the Clinical Laboratory, UCLA Medical Center.

\section{Results}

Injection of $M M-L D L$ induced inflammatory and oxidative stress responsive genes. In vitro studies have shown that MMLDL is a potent inducer of certain inflammatory and early response genes in a variety of cells, including fibroblasts, aortic endothelial cells, and smooth muscle cells. These genes include M-CSF and GM-CSF (3), tissue factor (35), JE/monocyte chemotactic protein-1 $(4,36)$ as well as c-fos, c-myc, and $\mathrm{KC}$ (an early response gene of unknown function ) (36). Moreover, MM-LDL induces endothelial cells to express a monocyte adhesion molecule that has not yet been identified (2) and increases adhesion of monocytes to the aortic wall in vivo (17). A number of these genes are likely to participate in monocyte recruitment, proliferation and activation in the artery wall during early atherogenesis.

Previously, we also demonstrated that the injection of MMLDL, prepared by either cold storage or brief iron oxidation, induced M-CSF activity in the plasma and JE mRNA in a variety of tissues (16). We have now surveyed expression of various inflammatory and oxidative stress responsive genes after intravenous injection of MM-LDL, and have observed significant induction of hepatic mRNA for $\mathrm{KC}$, members of the SAA family, and heme oxygenase. It is known that heme oxygenase is inducible by oxidants and agents affecting intracellular glutathione levels and, thus, is a sensitive indicator of oxidative stress (37). A representative study for the time course of hepatic gene induction after MM-LDL injection is shown in Fig. 1. Induction of the early response genes JE and $\mathrm{KC}$ was rapid and transient. Induction of JE mRNA was detectable $1 \mathrm{~h}$ after MM-LDL injection and in some experiments remained elevated by $4 \mathrm{~h}$. SAA induction was less rapid and more prolonged. Unlike JE, KC and SAA, which were barely detectable before MM-LDL injection, heme oxygenase was constitutively expressed in the liver. In response to MM-LDL injection there was a rapid induction of heme oxygenase mRNA, which returned to basal levels 6-9 h after injection (Fig. 1). Induction of mRNA for JE was observed in all of the tissues examined, including the lung, liver, and spleen (16).

Feeding of an atherogenic diet resulted in induction of the similar set of genes as MM-LDL injection. Atherogenic diets for mice were first developed by Thompson (38) and subsequently modified by Paigen and co-workers (39). The diet used contained $15.75 \%$ fat, $1.25 \%$ cholesterol, and $0.5 \%$ so- 


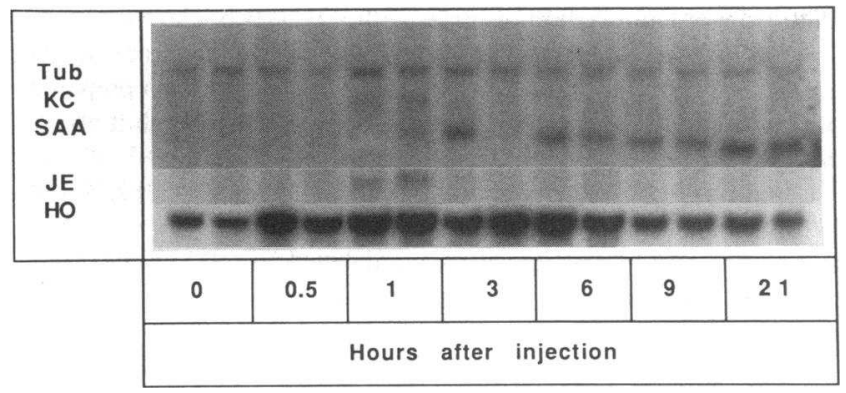

Figure 1. The time course of liver gene induction after intravenous injection of MM-LDL. MM-LDL was prepared by iron oxidation as previously described and reported (16). After intravenous injection at a dosage of $200 \mu \mathrm{g} /$ mouse, MM-LDL, but not LDL, induced JE mRNA in mouse livers (see Fig. 5 in reference 16). Both MM-LDL and LDL contained $<0.5 \mathrm{pg} \mathrm{LPS} / \mu \mathrm{g}$ protein. After administration of this MM-LDL at the time indicated in this figure, BALB/c mice were killed. Their hepatic RNA was extracted and subjected to northern analysis. Duplicate mice were used for each time point in this representative study. The mRNA levels for SAA, JE, KC, and heme oxygenase (HO) were clearly inducible while those for numerous other genes including tubulin (Tub) were unaffected.

dium cholate. In response to the diet, the mice showed large increases in the levels of apo B-containing lipoproteins (primarily $\beta$-very low density lipoproteins), which in most strains accumulated to a level of $200-400 \mathrm{mg} / \mathrm{dl}(40)$. In the majority of susceptible, but not resistant, strains consumption of the atherogenic diet also resulted in an $\sim 50 \%$ reduction in $\mathrm{HDL}$ levels (41). When susceptible C57BL/6 mice were fed the atherogenic diet for 4-5 wk, significant inductions of hepatic mRNA for JE (Figs. 2 and 4), heme oxygenase (Figs. 2 and 7 ), SAA (Figs. 4 and 6), and $\mathrm{KC}$ (data not shown) and of serum CSF activity (Fig. 3) were observed. This pattern of gene expression closely resembles that observed after MM-LDL injection. These inductions were clearly observed after 5 wk on the atherogenic diet and were maintained for $>15$ wk (data not shown). After prolonged ( $15 \mathrm{wk}$ ) exposure to the diet, induction of hepatic mRNA for c-fos and TNF- $\alpha$ was discernible, while no induction of IL- $1 \alpha$ was observed (data not shown). In

\begin{tabular}{|c|c|c|}
\hline $\begin{array}{c}\text { 18S rRNA } \\
\text { JE }\end{array}$ & \multicolumn{2}{|c|}{} \\
HO & \multicolumn{2}{|c|}{} \\
\hline Tissues & Sp Lu Li & Sp Lu Li \\
\hline Diets & Chow & Atherogenic \\
\hline
\end{tabular}

Figure 2. Comparison of JE and heme oxygenase (HO) mRNA in different tissues of $\mathrm{C} 57 \mathrm{BL} / 6$ mice on the chow or the atherogenic diet. An example from several studies is shown. $S p$, spleen; $L u$, lung; $\mathrm{Li}$, liver. Hybridization with $18 \mathrm{~S}$ rRNA probe was used to demonstrate equal loading of RNA. contrast to MM-LDL injection, dietary induction of gene expression occurred in the liver, a tissue exhibiting substantial lipid accumulation, but not in the lung and spleen (Fig. 2).

Genetic control of induction of inflammatory and oxidative stress responsive genes by the atherogenic diet. A variety of inbred strains of mice have been surveyed for susceptibility to the development of aortic fatty streaks. The best characterized are strains C57BL/6, BALB/c, and C3H/HeJ. Strain C57BL/ 6 mice begin to exhibit significant aortic lesions after about 8 wk on the diet and subsequently the lesion area continues to increase. BALB/c mice exhibit intermediate lesion susceptibility, with the first detectable lesions occurring after about $14 \mathrm{wk}$ on the atherogenic diet. Strain $\mathrm{C} 3 \mathrm{H} / \mathrm{HeJ}$ mice are completely resistant, with little or no lesion development after six or more months on the atherogenic diet $(41,42)$.

Induction of hepatic genes and circulating CSF activity were compared among these strains and some closely related sublines of these strains.

$\mathrm{C} 57 \mathrm{BL} / 6$ and $\mathrm{C} 3 \mathrm{H} / \mathrm{HeJ}$ mice were fed either the chow diet or the atherogenic diet for over 4 wk and their sera were collected for determination of CSF activity. CSF activity in the sera was markedly increased in C57BL/6 strain and did not show a significant change in $\mathrm{C} 3 \mathrm{H} / \mathrm{HeJ}$ strain (Fig. 3). The increased CSF activity in the sera of C57BL/6 mice was sustained for up to $15 \mathrm{wk}$ on the atherogenic diet.

After feeding the atherogenic diet, SAA and JE mRNA were dramatically induced in the livers of C57BL/6 mice (21and 15-fold, respectively), but both showed no significant induction in $\mathrm{C} 3 \mathrm{H} / \mathrm{HeJ}$ mice (Fig. 4). As shown in Fig. 5, after 5 wk of the atherogenic diet challenge, liver mRNA for SAA and $\mathrm{JE}$ was highly expressed in $\mathrm{C} 57 \mathrm{BL} / 6$ mice, showed intermediate induction in $\mathrm{BALB} / \mathrm{c}$, and was lowest in $\mathrm{C} 3 \mathrm{H} / \mathrm{HeJ}$ mice,

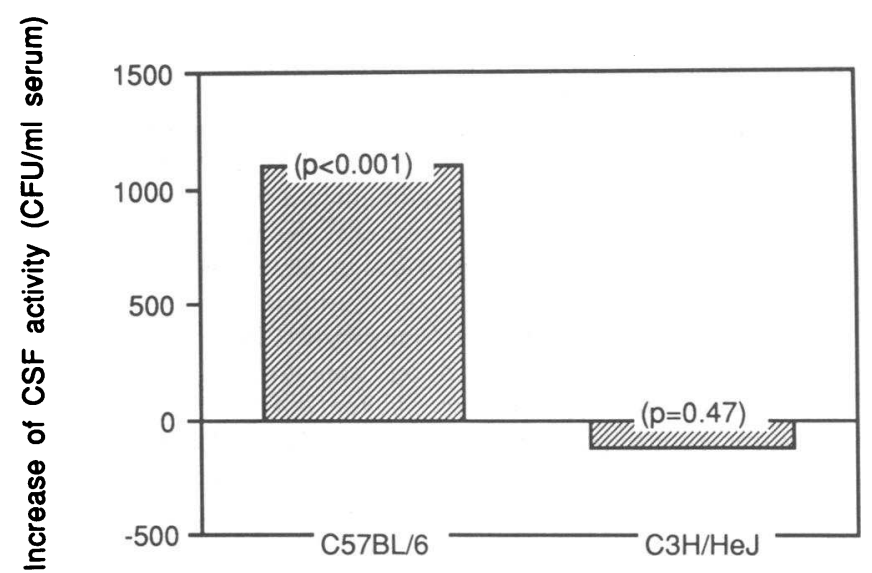

Figure 3. Induction of CSF activity in the sera of C57BL/6 and $\mathrm{C} 3 \mathrm{H} / \mathrm{HeJ}$ mice. After $4 \mathrm{wk}$ on the atherogenic diet the mice were compared with their counterparts on the chow diet for serum CSF activity as determined by mouse bone marrow cell colony formation assay (16). Significant increases in the levels of serum CSF activity were observed in C57BL/ 6 mice on the atherogenic diet $(1,786 \pm 138$ $\mathrm{CFU} / \mathrm{ml}$ serum, $n=9$ ) compared to those on the chow diet $(688 \pm 126 \mathrm{CFU} / \mathrm{ml}$ serum, $n=10) . \mathrm{C} 3 \mathrm{H} / \mathrm{HeJ}$ mice, in contrast, did not exhibit a significant change between the group on the atherogenic $\operatorname{diet}(780 \pm 60 \mathrm{CFU} / \mathrm{ml}$ serum, $n=5)$ and the group on the chow $\operatorname{diet}(900 \pm 230 \mathrm{CFU} / \mathrm{ml}$ serum, $n=5)$. The numbers shown are the mean $\pm \mathrm{SEM}$ CFU $/ \mathrm{ml}$ serum. $P$ values for the differences between the chow and the atherogenic diet groups obtained by Student's $t$ test are shown in the figure. 


\begin{tabular}{|c|c|c|c|c|}
\hline JE/18S rRNA & $1.9 \pm 0.3$ & $1.0 \pm 0.3$ & $11.8 \pm 4.0$ & $0.8 \pm 0.3$ \\
\hline SAA/18S rRNA & $4.0 \pm 1.3$ & $3.4 \pm 1.7$ & $22.5 \pm 1.8$ & $1.1 \pm 0.2$ \\
\hline 18S rRNA & & & & \\
\hline JE & & & & 8 \\
\hline SAA & & & & \\
\hline Diets & Atherogenic & Chow & Atherogenic & Chow \\
\hline Strains & \multicolumn{2}{|c|}{$\mathrm{C} 3 \mathrm{H} / \mathrm{HeJ}$} & \multicolumn{2}{|c|}{ C57BL/6 } \\
\hline
\end{tabular}

Figure 4. Differential induction of JE and SAA mRNA in the livers of $\mathrm{C} 57 \mathrm{BL} / 6$ and $\mathrm{C} 3 \mathrm{H} / \mathrm{HeJ}$ mice upon challenge with the atherogenic diet. Mice (in triplicate) were fed either the chow diet or the atherogenic diet for $4 \mathrm{wk}$ and were studied for the levels of hepatic mRNA for SAA, JE, and 18S rRNA by Northern analysis. The results of densitometry scans are shown at the top of the figure as the ratio of densitometry units of the particular mRNA to that of $18 \mathrm{~S}$ rRNA (mean \pm SEM).

the same rank order for their susceptibility to aortic lesion formation. After $15 \mathrm{wk}$ of the exposure to the atherogenic diet, mRNA levels were about the same in BALB/c and C57BL/6 mice, but remained much lower in the $\mathrm{C} 3 \mathrm{H} / \mathrm{HeJ}$ mice (data not shown). Thus, after challenge with the atherogenic diet, strain BALB/c mice exhibit a substantial lag in both aortic fatty streak development and inflammatory gene induction as compared to strain C57BL/6 mice.

SAA consists of a family of proteins encoded by genes clustered on mouse chromosome 7. Among them $\mathrm{SAA}_{1}$ and $\mathrm{SAA}_{2}$ are the major acute phase response species. Using oligonucleotides specific for $\mathrm{SAA}_{1}$ and $\mathrm{SAA}_{2}$ we found that both of them were induced in the same pattern as that observed using $\mathrm{SAA}_{3}$

\begin{tabular}{|c|c|c|c|}
\hline SAA $/ 18 S$ rRNA & $3.3 \pm 0.6$ & $19.6 \pm 3.6$ & $5.8 \pm 0.9$ \\
\hline JE/18S rRNA & $1.9 \pm 0.3$ & $11.5 \pm 3.0$ & $3.0 \pm 0.1$ \\
\hline 18S rRNA & & & \\
\hline SAA & th $=1$ & & \\
\hline JE & & & \\
\hline Strains & СзH/HeJ & $\mathrm{C} 57 \mathrm{BL} / 6$ & BALB/c \\
\hline
\end{tabular}

Figure 5. Comparison of JE and SAA mRNA expression in the livers of $\mathrm{C} 3 \mathrm{H} / \mathrm{HeJ}, \mathrm{C} 57 \mathrm{BL} / 6$, and $\mathrm{BALB} / \mathrm{c}$ mice on the atherogenic diet for $5 \mathrm{wk}$. Duplicate mice are shown as representative examples. $18 \mathrm{~S}$ rRNA was used for reference. The results of densitometry scans are shown at the top of the figure as the ratio of densitometry units of the particular mRNA to that of $18 \mathrm{~S}$ rRNA (mean \pm SEM). Three to six animals were included in each group.

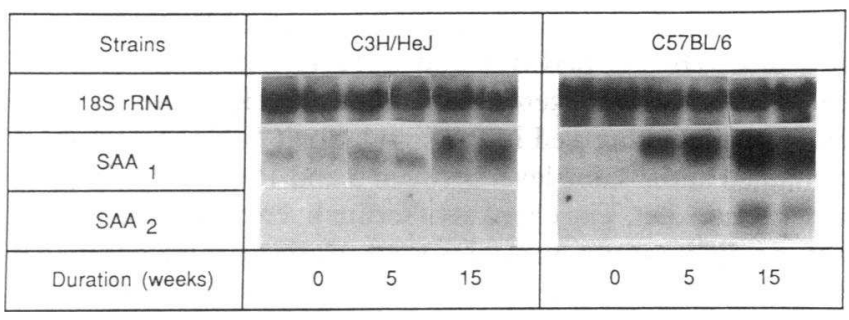

Figure 6. Differential induction of the major inflammatory SAA mRNA in the livers of $\mathrm{C} 57 \mathrm{BL} / 6$ versus $\mathrm{C} 3 \mathrm{H} / \mathrm{HeJ}$ mice. Both $\mathrm{C} 57 \mathrm{BL} / 6$ and $\mathrm{C} 3 \mathrm{H} / \mathrm{HeJ}$ mice were fed the atherogenic diet for 0,5 , or $15 \mathrm{wk}$ and were compared for the levels of $\mathrm{SAA}_{1}$ and $\mathrm{SAA}_{2}$ mRNA in livers using end-labeled specific oligonucleotides. Duplicate mice are shown as representatives of several studies. 18S rRNA was used for reference.

cDNA probe in the livers of mice injected with MM-LDL and also in the livers of $\mathrm{C} 57 \mathrm{BL} / 6$ versus $\mathrm{C} 3 \mathrm{H} / \mathrm{HeJ}$ mice on the atherogenic diet (Fig. 6). Moreover, the induction of $\mathrm{SAA}_{1}$ and $\mathrm{SAA}_{2}$ mRNA correlated with the change of their proteins in the plasma as revealed by immunoblotting studies (data not shown). A fourfold induction of heme oxygenase mRNA was also noted in the livers of C57BL/ 6 mice after 5 wk of feeding the atherogenic diet while no significant change in $\mathrm{C} 3 \mathrm{H} / \mathrm{HeJ}$ mice was observed (Fig. 7). This difference remained the same between these two strains after $15 \mathrm{wk}$ on the atherogenic diet. Other fatty streak resistant mice, $\mathrm{C} 3 \mathrm{H} / \mathrm{HeSN}$ and BALB/c, also exhibited lower levels of heme oxygenase mRNA than susceptible C57BL/6 mice (data not shown).

Histological examination of the livers was performed for $\mathrm{C} 57 \mathrm{BL} / 6$ and $\mathrm{C} 3 \mathrm{H} / \mathrm{HeJ}$ mice on the atherogenic diet for 0,5 , and $15 \mathrm{wk}$. The atherogenic diet not only increased lipid loading and adaptive morphological change in the parenchymal cells but also caused mononuclear cell infiltration. Consistent with the minimal induction for inflammatory genes, the livers of $\mathrm{C} 3 \mathrm{H} / \mathrm{HeJ}$ mice exhibited much milder inflammation with the presence of fewer and smaller foci of infiltrating mononuclear cells (data not shown). Assays for hepatic enzymes alkaline phosphatase (ALK), alanine aminotransferase (ALT),

\begin{tabular}{|c|c|c|c|c|}
\hline HO/18S rRNA & $2.6 \pm 0.4$ & $1.9 \pm 0.3$ & $5.3 \pm 0.6$ & $1.4 \pm 0.2$ \\
\hline 18S rRNA & \multicolumn{3}{|c|}{} \\
\hline Heme oxygenase & \multicolumn{3}{|c|}{} \\
\hline Diets & Ath & Chow & Ath & Chow \\
\hline Strains & \multicolumn{2}{|c|}{$\mathrm{C} 3 \mathrm{H} / \mathrm{HeJ}$} & \multicolumn{2}{|c|}{$\mathrm{C} 57 \mathrm{BL} / 6$} \\
\hline
\end{tabular}

Figure 7. Differential induction of heme oxygenase mRNA in the livers of $\mathrm{C} 57 \mathrm{BL} / 6$ and $\mathrm{C} 3 \mathrm{H} / \mathrm{HeJ}$ mice fed the atherogenic diet. Mice were fed either the chow or the atherogenic diet for $5 \mathrm{wk}$ and compared for the levels of mRNA for heme oxygenase (HO) as shown in representative duplicates. 18S rRNA was used for reference. The results of densitometry scans are shown at the top of the figure as the ratio of densitometry unit of heme oxygenase mRNA to that of $18 \mathrm{~S}$ rRNA (mean \pm SEM). Six or seven animals in each group were used for the experiments. Ath, the atherogenic diet. 
and aspartate aminotransferase (AST) were performed for the sera of $\mathrm{C} 57 \mathrm{BL} / 6, \mathrm{BALB} / \mathrm{c}$ and $\mathrm{C} 3 \mathrm{H} / \mathrm{HeJ}$ mice on both the chow and the atherogenic diets. Minimal elevations of these enzymes were observed in the circulation (Table I), and these remained at the same level between 5 and $15 \mathrm{wk}$ of feeding the atherogenic diet. The changes of serum liver enzymatic activity among different mouse strains were relatively mild, compared to an $11,000 \%$ increase in serum ALT and a 4,000\% increase in serum AST as reported in murine viral hepatitis (43). Moreover, these mild elevations did not correlate with the differential hepatic gene induction observed among the strains.

Significantly higher levels of lipid peroxidation in the livers of susceptible as compared to resistant strains. After being placed on the atherogenic diet for 8 or $15 \mathrm{wk}$, liver total lipids increased four- to sixfold in the livers of both $\mathrm{C} 3 \mathrm{H} / \mathrm{HeJ}$ and C57BL/ 6 mice. Total lipid levels were slightly (although not significantly) higher in $\mathrm{C} 57 \mathrm{BL} / 6$ than in $\mathrm{C} 3 \mathrm{H} / \mathrm{HeJ}$ mice (Fig. 8 ). Lipid peroxidation products were also increased in the livers of the mice fed the atherogenic diet. Conjugated dienes associated with hepatic total lipids were undetectable when the mice were on the chow diet. After feeding the atherogenic diet for either 8 or $15 \mathrm{wk}$, the amount of conjugated dienes per gram wet weight of liver in C57BL/ 6 was nearly double that in $\mathrm{C} 3 \mathrm{H} /$ HeJ mice (Fig. 8). This difference was observed in two separate studies, each involving multiple animals, and was highly significant $(P<0.001$ and 0.025 , respectively).

Genetic control of induction of $N F-\kappa B$-like activity by the atherogenic diet. A number of inflammatory response genes, including JE and SAA, contain NF- $\kappa$ B binding sites in their promoters $(20,21)$. Numerous transcription factors recognizing the concensus binding sequence have been identified in the $N F-\kappa B$ family. Since NF $-\kappa B$ has been reported to be responsive to oxidative stress (19), we examined if there was differential induction of $\mathrm{NF}-\kappa \mathrm{B}$ or its isoforms in the livers of $\mathrm{C} 3 \mathrm{H} / \mathrm{HeJ}$ and $\mathrm{C} 57 \mathrm{BL} / 6$ mice in response to the consumption of the atherogenic diet. To investigate whether or not NF- $\kappa$ B-like activity correlated with the levels of the hepatic genes described above, nuclear extracts were prepared from the livers of $\mathrm{C} 3 \mathrm{H} / \mathrm{HeJ}$ and $\mathrm{C} 57 \mathrm{BL} / 6$ mice and an oligonucleotide recognizing the consensus sequence of the binding site of the NF- $\kappa \mathrm{B}$ family was used for mobility shift assays. As shown in Fig. $9 A$ there was an

Table I. Effect of the Atherogenic Diet on Serum Levels of Hepatic Enzymes

\begin{tabular}{llccc}
\hline Enzymes & Diets & C3H/HeJ & C57BL/6 & BALB/c \\
\hline ALK & & & & \\
$\quad$ (IU/liter) & Con & $96 \pm 2$ & $95 \pm 3$ & $109 \pm 4$ \\
& Ath & $136 \pm 19$ & $133 \pm 7$ & $113 \pm 0$ \\
ALT & & & & \\
$\quad$ (IU/liter) & Con & $44 \pm 15$ & $29 \pm 5$ & $54 \pm 17$ \\
& Ath & $190 \pm 76$ & $118 \pm 18$ & $54 \pm 21$ \\
AST & & & & \\
(IU/liter) & Con & $83 \pm 26$ & $81 \pm 17$ & $89 \pm 32$ \\
& Ath & $196 \pm 44$ & $140 \pm 33$ & $82 \pm 24$ \\
& & & & \\
\hline
\end{tabular}

Sera were collected from $\mathrm{C} 3 \mathrm{H} / \mathrm{HeJ}, \mathrm{C} 57 \mathrm{BL} / 6$, and BALB/c mice after 15 wk on the atherogenic diet and their counterparts on the chow diet (three to five in each group). Assays for ALK, ALT, and AST were performed. The values are mean \pm SEM. Con, control diet; Ath, atherogenic diet.
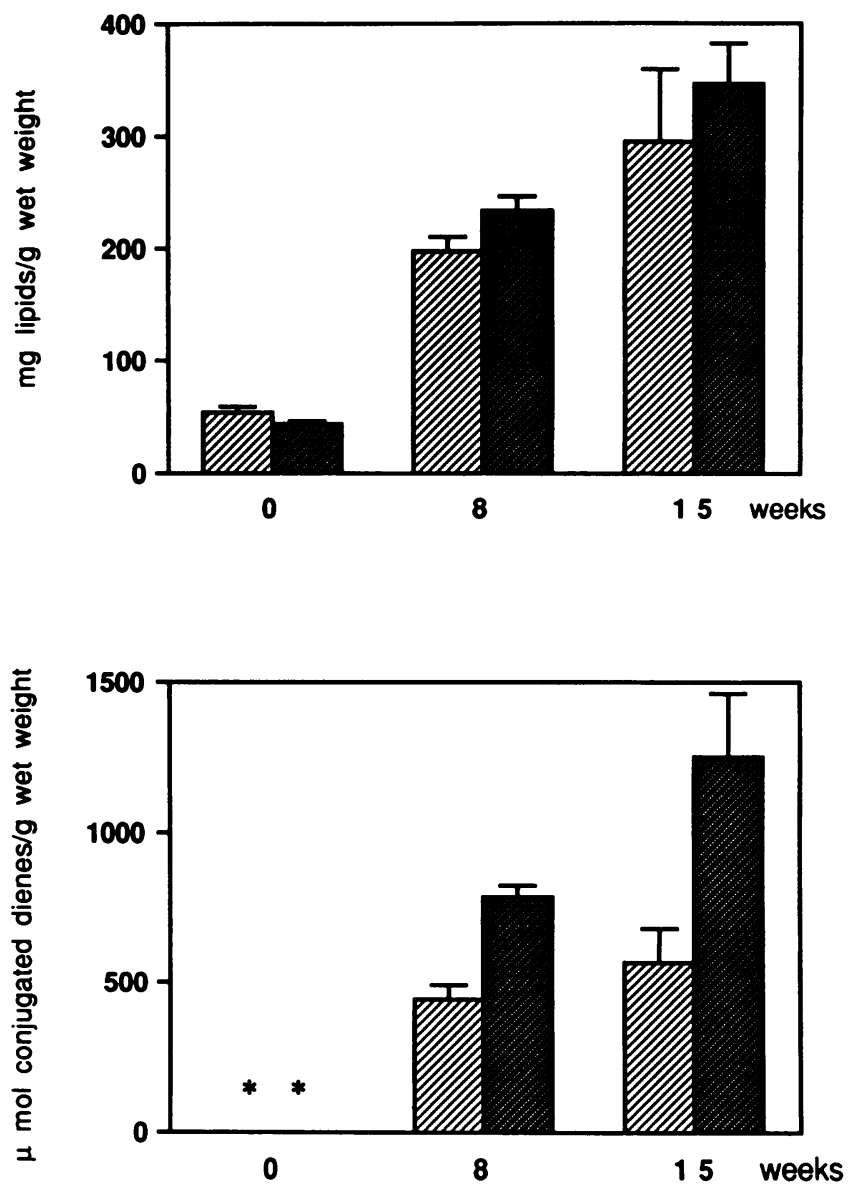

Figure 8. Total lipids ( upper panel) and conjugated dienes (lower panel) in the livers of C57BL/6 (dark hatched bars) and $\mathrm{C} 3 \mathrm{H} / \mathrm{HeJ}$ mice (light hatched bars). After 0,8 , and $15 \mathrm{wk}$ of feeding the atherogenic diet, $\mathrm{C} 57 \mathrm{BL} / 6$ and $\mathrm{C} 3 \mathrm{H} / \mathrm{HeJ}$ mice were killed, their liver lipids were extracted, and the amount of conjugated dienes determined. For each strain, 5, 9, and 5 mice were used for the 0-, 8-, and 15-wk time points, respectively. The $P$ values for the difference of total lipid content between $\mathrm{C} 57 \mathrm{BL} / 6$ and $\mathrm{C} 3 \mathrm{H} / \mathrm{HeJ}$ were $0.137,0.042$, and 0.489 at $0-, 8-$, and 15 -wk points, respectively. The asterisk indicates that the levels of conjugated dienes were undetectable when mice were on the chow diet. Significantly higher levels of conjugated dienes were present in the livers of $\mathrm{C} 57 \mathrm{BL} / 6$ than in $\mathrm{C} 3 \mathrm{H} / \mathrm{HeJ}$ mice after both $8 \mathrm{wk}(P<0.001)$ and $15 \mathrm{wk}(P<0.025)$. The values are the mean \pm SEM.

activation of NF- $\kappa$ B-like factor(s) in the livers of C57BL/6 mice after 5 and $15 \mathrm{wk}$ of the atherogenic diet challenge. No such an activation was observed, however, in the livers of $\mathrm{C} 3 \mathrm{H} / \mathrm{HeJ}$ mice after exposure to the atherogenic diet for the same period of time (Fig. $9 \mathrm{~B}$ ). The levels of SP-1 (a constitutive transcription factor) did not differ between the two strains (Fig. $9 \mathrm{C}$ ). Thus it is apparent that feeding the atherogenic diet provides a sufficient stimulus to activate NF- $\kappa$ B-like factor(s) in the livers of mice with a susceptible genetic background. Activation of the NF- $\kappa$ B family may, in turn, cause transcriptional activation of inflammatory response genes such as JE and SAA.

\section{Discussion}

Our results indicate that feeding the atherogenic diet to mice resulted in induction of inflammatory and oxidative stress re- 

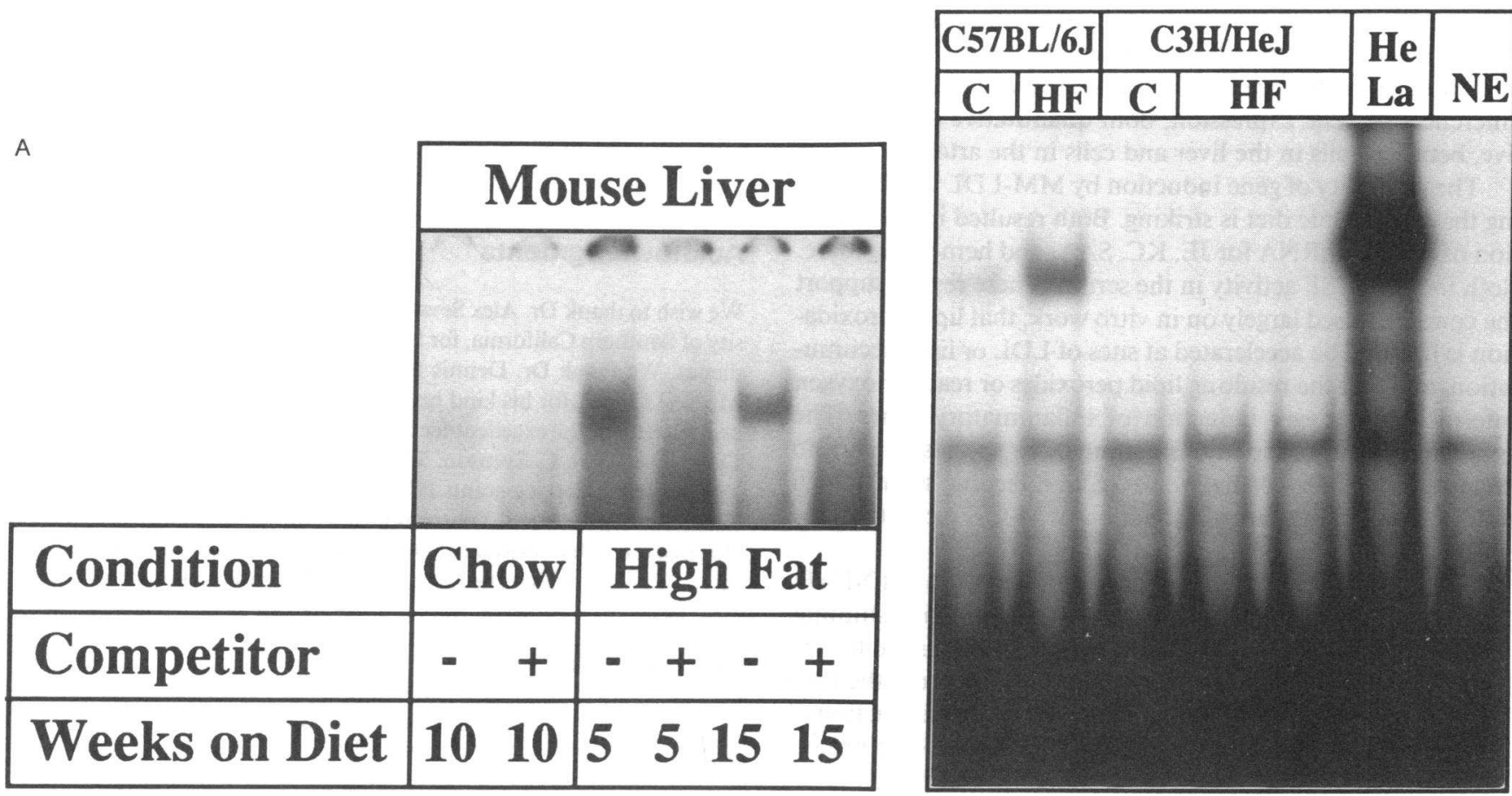

C

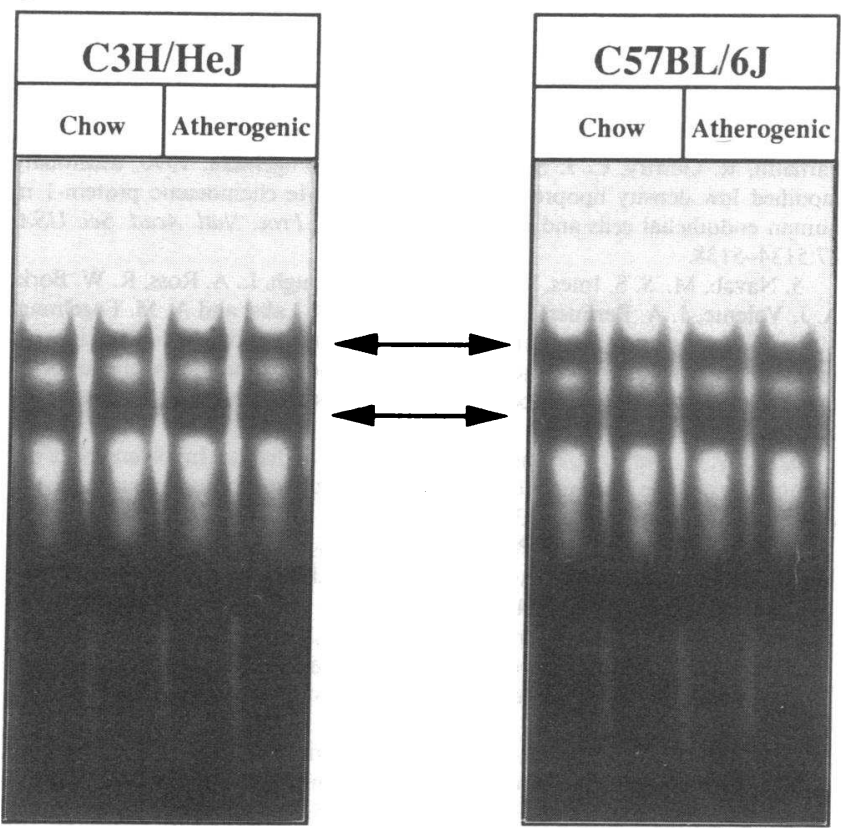

sponsive genes, and suggest that such induction likely involved the activation of NF- $\kappa$ B-like transcription factor(s). Furthermore, the pattern of gene induction was remarkably similar to that produced by injection of MM-LDL, and the gene induction among different inbred strains of mice corresponded to the levels of lipid peroxide accumulation and to the susceptibility to fatty streak development. These findings provide strong support for the concept that the products of lipid peroxidation are potent inducers of inflammatory genes, including some that are likely to contribute to the early stages of atherogenesis. They also help to define, at the molecular level, the nature of
Figure 9. (A) Activation of NF- $\kappa \mathrm{B}-$ like transcription factor(s) in the livers of C57BL/ 6 mice on the atherogenic diet. Animals were maintained on the chow or the atherogenic diet for the indicated periods. Nuclear extracts were prepared from the livers and mobility shift assays were performed using an oligonucleotide containing two NF- $\kappa B$ family binding sites. - indicates the absence of a 50 -fold molar excess of unlabeled NF- $\kappa$ B-like competitor oligonucleotide; + indicates the presence of a 50-fold molar excess of unlabeled NF- $\kappa$ B-like competitor oligonucleotide. $(B)$ Differential effect of the atherogenic diet on NF- $\kappa$ B-like activation in livers of $\mathrm{C} 57 \mathrm{BL} / 6$ and $\mathrm{C} 3 \mathrm{H} / \mathrm{HeJ}$ mice. Animals were fed the chow or the atherogenic diet for $15 \mathrm{wk}$. Nuclear extracts were prepared from the livers and mobility shift assays were performed using an oligonucleotide containing two NF- $\kappa$ B family binding sites. A representative result of several studies is shown. HeLa cells, treated with $100 \mathrm{ng} / \mathrm{ml}$ of bacterial LPS for $1 \mathrm{~h}$, served as a positive control. NE indicates no nuclear extracts. $(C)$ The activity of $\mathrm{SP}-1$ was the same in both $\mathrm{C} 57 \mathrm{BL} / 6$ and $\mathrm{C} 3 \mathrm{H} / \mathrm{HeJ}$ mice on the chow and the atherogenic diets. Animals were fed the chow or the atherogenic diet for $15 \mathrm{wk}$. Nuclear extracts were prepared from the livers and mobility shift assays were performed using an oligonucleotide containing SP-1 binding site. A representative result of several studies is shown.

the genetic differences among strains of mice that determine their susceptibility to early atherogenesis.

Our data reveal that the feeding of the atherogenic diet to mice results in lipid and lipid peroxide accumulation in the liver. Presumably, a similar process occurs in the aorta and other arteries, but it is difficult to measure directly given the small size of blood vessels in mice. The aortic fatty streaks of susceptible C57BL/ 6 mice closely resemble those in other mammalian species in the presence of apo B containing lipoproteins and monocyte-macrophage foam cells (44). Because of the relatively large size of the liver, and because MM-LDL 
induces gene expression in the liver as well as vascular cells, we have used the liver as a model organ to study the inflammation elicited by lipid accumulation and the relationship of this phenomenon to atherogenesis. Of course, there are clearly many differences in gene expression, both quantitative and qualitative, between cells in the liver and cells in the artery.

The similarity of gene induction by MM-LDL and by feeding the atherogenic diet is striking. Both resulted in the induction of hepatic mRNA for JE, KC, SAA, and heme oxygenase. Both induced CSF activity in the serum. These results support the concept, based largely on in vitro work, that lipid peroxidation is likely to be accelerated at sites of LDL or lipid accumulation, and that the resulting lipid peroxides or reactive oxygen intermediates trigger induction of inflammatory genes. The generality of our observations among other species remains to be tested. It is noteworthy, however, that feeding swine a high fat diet resulted in marked induction of M-CSF activity in the serum (18).

The induction of heme oxygenase and activation of NF- $\kappa$ Blike transcription factor(s) suggest that an oxidative stimulus resulting from lipid peroxidation could be responsible for the induction of inflammatory genes. Heme oxygenase is the ratelimiting enzyme in the degradation of heme. The induction of heme oxygenase by oxidative stress is considered to be a protective system because it decreases certain potential pro-oxidants and simultaneously increases the production of bilirubin, an endogenous antioxidant (37). The activation of NF- $k$ B-like transcription factor(s) is likely to underlie, in part, the inflammatory gene induction. NF- $\kappa \mathrm{B}$ is known to be activated by reactive oxygen intermediates in tissue culture cells, and we have now shown that a diet that caused hepatic lipid and conjugated diene accumulation also activated the NF- $\kappa$ B family in the liver. The promoter regions of some of the induced genes reported here are known to contain NF- $\kappa$ B binding motifs $(20$, 21 ). Furthermore, MM-LDL has recently been shown to be a potent inducer of NF- $\kappa$ B-like transcription factor(s) in cultured aortic endothelial cells (45).

The induction of the major members of the inflammatory SAA family by the atherogenic diet may be of significance in terms of lipoprotein metabolism. It may explain, in part, the previous findings that susceptibility to atherogenesis is associated with decreased levels of HDL in different strains of mice upon exposure to the atherogenic diet (41). SAA is known to bind avidly to HDL and has been reported to displace apolipoproteins AI and AII. The resulting remodeling of the particle could certainly affect its functional properties and perhaps its turnover as well. Overexpression of human apolipoprotein AI in transgenic mice has been reported to be protective against the dietary induced decrease of HDL and development of fatty streaks in susceptible mice (46). Patients with chronic rheumatoid arthritis exhibit elevated levels of acute phase SAA and, although clearly not definitive, certain studies suggest that these patients develop accelerated atherosclerosis (47-49). A chronic inflammatory state may be occurring in the animals fed the atherogenic diet for prolonged periods as indicated by an increase in the levels of SAA mRNA and proteins in C57BL/ 6 mice. More experimentation is needed to address these issues and elucidate the positive and negative roles of inflammatory gene products such as SAA in acute and chronic inflammation.

Our results have shed new light on the mechanisms contributing to differences in fatty streak development among various inbred strains of mice. They suggest that inflammatory processes induced by lipid peroxidation may be of primary importance. Such processes could be influenced by a variety of proteins, including those of the glutathione system, superoxide dismutases, phospholipases, and lipoxygenases. Thus, our results provide new candidate genes for future studies on the genetic control of atherogenesis.

\section{Acknowledgments}

We wish to thank Dr. Alex Sevanian, Institute for Toxicology, University of Southern California, for his advice on the analysis of conjugated dienes. We thank Dr. Dennis Rogerson, Clinical Laboratory, UCLA Medical Center, for his kind help in the assays of serum enzymes. We are grateful for the excellent technical assistance of Yu-Rong Xia, Anh Diep, and Karen L. Svenson. This work was supported in part by US Public Health Service grants HL-30568 and HL-28481, the Laubisch Fund, the Cigarette and Tobacco-Surtax Fund of the State of California through the Tobacco-Related Disease Research Program at the University of California, and the Council for Tobacco Research-U.S.A., Inc.

\section{References}

1. Witztum, J. L., and D. Steinberg. 1991. Role of oxidized low density lipoprotein in atherogenesis. J. Clin. Invest. 88:1785-1792.

2. Berliner, J. A., M. C. Territo, A. Sevanian, S. Ramin, J. A. Kim, B. Bamshad, M. Esterson, and A. M. Fogelman. 1990. Minimally modified low density lipoprotein stimulates monocyte endothelial cell interaction. J. Clin. Invest. 85:1260-1266.

3. Rajavashisth, T. B., A. Andalibi, M. C. Territo, J. A. Berliner, M. Navab, A. M. Fogelman, and A. J. Lusis. 1990. Induction of endothelial cell expression of granulocyte and macrophage colony-stimulating factors by modified low density low density lipoproteins. Nature (Lond.). 344:254-257.

4. Cushing, S. D., J. A. Berliner, A. J. Vanlente, M. C. Territo, M. Navab, F. Parhami, R. Gerrity, C. J. Schwartz, and A. M. Fogelman. 1990. Minimally modified low density lipoprotein induces monocyte chemotactic protein-1 in human endothelial cells and smooth muscle cells. Proc. Natl. Acad. Sci. USA. 87:5134-5138.

5. Navab, M., S. S. Imes, S. Y. Hama, G. P. Hough, L. A. Ross, R. W. Bork, A. J. Valente, J. A. Berliner, D. C. Drinkwater, H. Laks, and A. M. Fogelman. 1991. Monocyte transmigration induced by modification of low density lipoprotein in coculture of human aortic wall cells is due to induction of monocyte chemotactic protein 1 and is abolished by high density lipoprotein. J. Clin. Invest. 88:2039-2046.

6. Libby, P., and G. K. Hansson. 1991. Biology of disease. Involvement of the immune system in human atherogenesis: current knowledge and unanswered questions. Lab. Invest. 64:5-13.

7. Hajjar, D. P., and K. B. Pomerantz. 1992. Signal transduction in atherosclerosis: integration of cytokines and the eicosanoid network. FASEB (Fed. Am. Soc. Exp. Biol.) J. 6:2933-2941.

8. Clinton, S. K., R. Underwood, L. Hayes, M. L. Sherman, D. W. Kufe, and P. Libby. 1992. Macrophage colony-stimulating factor gene expression in vascular cells and in experimental and human atherosclerosis. Am. J. Pathol. 140:301316.

9. Rosenfeld, M. E., S. Yla-Herttuala, B. A. Lipton, V. A. Ord, J. L. Witztum, and D. Steinberg. 1992. Macrophage colony-stimulating factor mRNA and protein in atherosclerotic lesion of rabbits and humans. Am. J. Pathol. 140:291-300.

10. Yla-Harttuala, S., B. A. Lipton, M. E. Rosenfeld, T. Sarkioja, T. Yoshimura, E. J. Leonard, J. L. Witztum, and D. Steinberg. 1991. Expression of monocyte chemoattractant protein 1 in macrophage-rich areas of human and rabbit atherosclerotic lesions. Proc. Natl. Acad. Sci. USA. 88:5252-5256.

11. Haberland, M. E., D. Fong, and L. Cheng. 1988. Malondialdehyde-altered protein occurs in atheroma of Watanabe heritable hyperlipidemic rabbits. Science (Wash. DC). 241:215-218.

12. Yla-Herttuala, S., W. Palinski, M. E. Rosenfeld, S. Parthasarathy, T. E. Carew, S. Butler, J. L. Witztum, and D. Steinberg. 1989. Evidence for the presence of oxidatively modified low density lipoprotein in atherosclerotic lesions of rabbit and man. J. Clin. Invest. 84:1086-1095.

13. Palinski, W., M. E. Rosenfeld, S. Yla-Herttuala, G. C. Gurtner, S. S. Socher, S. W. Butler, S. Parthasarathy, T. E. Carew, D. Steinberg, and J. L. Witztum. 1989. Low density lipoprotein undergoes oxidative modification in vivo. Proc. Natl. Acad. Sci. USA. 86:1372-1380.

14. Avogaro, P., G. B. Bon, and G. Cazzolato. 1988. Presence of a modified low density lipoprotein in human. Arteriosclerosis. 8:79-87. 
15. Chisolm, G. M. 1991. Antioxidants and atherosclerosis: a current assessment. Clin. Cardiol. 14:I-25-30.

16. Liao, F., J. A. Berliner, M. Mehrabian, M. Navab, L. L. Demer, A. J. Lusis, and A. M. Fogelman. 1991. Minimally modified low density lipoprotein is biologically active in vivo in mice. J. Clin. Invest. 87:2253-2257.

17. Berliner, J. A., M. Territo, A. Andalibi, M. Navab, F. Liao, S. Cushing, S. Imes, J. Kim, B. Van Lenten, A. J. Lusis, and A. M. Fogelman. 1992. Modified lipoproteins and atherogensis. In Cellular and Molecular Biology of Atherosclerosis. J. A. M. Gotto, editor. Springer-Verlag London Limited. 77-80.

18. Averill, L. E., R. C. Meagher, and R. G. Gerrity. 1989. Enhanced monocyte progenitor cell proliferation in bone marrow of hyperlipemic swine. Am.J. Pathol. 135:369-377.

19. Schreck, R., P. Rieber, and P. A. Baeuerle. 1991. Reactive oxygen intermediates as apparently widely used messengers in the activation of the NF- $\mathrm{kB}$ transcription factor and HIV-1. EMBO (Eur. Mol. Biol. Organ.) J. 10:22472258.

20. Visvanathan, K. V., and S. Goodbourn. 1989. Double-stranded RNA activates binding of NF- $\mathrm{KB}$ to an inducible element in the human $\beta$-interferon promoter. EMBO (Eur. Mol. Biol. Organ.) J. 8:1129-1138.

21. Li, X., and W. S.-L. Liao. 1991. Expression of rat serum amyloid A1 gene involves both C/EBP-like and NF-kB-like transcription factors. J. Biol. Chem. 23:15192-15201.

22. Chomczynski, P., and N. Sacchi. 1987. Single-step method of RNA isolation by acid guanidinium thiocyanate-phenol-chloroform extraction. Anal. Biochem. 162:156-159.

23. Rollins, B. J., E. D. Morrison, and C. D. Stille. 1988. Cloning and expression of $\mathrm{JE}$, a gene inducible by platelet derived growth factor and whose product has cytokine-like properties. Proc. Natl. Acad. Sci. USA. 85:3738-3742.

24. Cochran, B. H., A. C. Reffel, and C. D. Stille. 1983. Molecular cloning of gene sequence regulated by platelet derived factor. Cell. 33:939-947.

25. Oberbäumer, I. 1992. Retroposons do jump: a B2 element recently integrated in an 18S rDNA gene. Nucleic Acids Res. 20:671-677.

26. Kageyama, H., T. Hiwasa, K. Tokunaga, and S. Sakiyama. 1988. Isolation and characterization of a complementary DNA clone for a Mr 32,000 protein which is induced with tumor promoters in BALB/c 3T3 cells. Cancer Res. 48:4795-4798.

27. Lomedico, P. T., U. Gubler, C. P. Hellmann, M. Dukovich, J. G. Giri, Y. E. Pan, K. Collier, R. Semionow, A. O. Chua, and S. B. Mizel. 1984. Cloning and expression of murine interleukine-1 cDNA in Escherichia coli. Nature (Lond.). 312:458-462.

28. Morrow, J. C., R. S. Stearman, C. G. Peltzman, and D. A. Potter. 1981 Induction of hepatic synthesis of serum amyloid A protein and actin. Proc. Natl. Acad. Sci. USA. 78:4718-4722.

29. Stearman, R. S., C. A. Lowell, C. G. Peltzman, and J. F. Morrow. 1986. The sequence and structure of a new serum amyloid A gene. Nucleic Acids Res. 14:797-809.

30. Zahedi, K., W. A. Gonnerman, F. C. deBeer, M. C. deBeer, D. M. Steel, J. D. Sipe, and A. S. Whitehead. 1991. Major acute-phase reactant synthesis during chronic inflammation in amyloid-susceptible and resistant mouse strains. Inflammation. 15:1-14.

31. Folch, J., M. Lees, and G. H. Sloane Stanley. 1957. A simple method for the isolation and purification of total lipids from animal tissues. J. Biol. Chem. 226:497-509.
32. Corongiu, F. P., S. Banni, and M. A. Dessi. 1989. Conjugated dienes detected in tissue lipid extraction by second derivative spectrophotometry. Free Radical Biol. \& Med. 7:183-186.

33. Dignam, J. D., R. M. Lebovitz, and R. G. Roeder. 1983. Accurate transcription initiation by RNA polymerase II in a soluble extract from isolated mammalian nuclei. Nucleic Acids Res. 11:1475-1498.

34. Osborn, L., S. Kunkel, and G. J. Nabel. 1989. Tumor necrosis factor $\alpha$ and interleukin 1 stimulate the human immunodeficiency virus enhancer by activation of the nuclear factor kB. Proc. Natl. Acad. Sci. USA. 86:2336-2340.

35. Drake, T. A., K. Hannani, F. Haihua, S. Lavi, and J. B. Berliner. 1991. Minimally oxidized low-density lipoprotein induced tissue factor expression in cultured human endothelial cells. Am. J. Pathol. 138:601-607.

36. Bork, R. W., K. L. Svenson, M. Mehrabian, A. J. Lusis, A. M. Fogelman, and P. A. Edwards. 1992. Mechanism controlling competence gene expression in murine fibroblasts stimulated with minimally modified LDL. Arterioscler. Thromb. 12:800-806.

37. Stocker, R. 1990. Induction of heme oxygenase as a defence against oxidative stress. Free Radical Res. Commun. 9:101-112.

38. Thompson, J. S. 1969. Atheroma in an inbred inbred strain of mice. $J$. Atheroscler. Res. 10:113-122.

39. Paigen, B., A. Morrow, C. Brandon, D. Mitchell, and P. Holmes. 1985. Variation in susceptibility to atherosclerosis among inbred strains of mice. Atherosclerosis. 57:65-73.

40. Lusis, A. J., B. A. Taylor, D. Quon, S. Zollman, and R. C. LeBoeuf. 1987. Genetic factors controlling structure and expression of apolipoproteins $B$ and $E$ in mice. J. Biol. Chem. 262:7594-7604.

41. Paigen, B., D. Mitchell, K. Reue, A. Morrow, A. L. Lusis, and R. C. LeBoeuf. 1987. Ath-1, a gene determining atherosclerosis susceptibility and high density lipoprotein levels in mice. Proc. Natl. Acad. Sci. USA. 84:3763-3767.

42. Paigen, B., B. Y. Ishida, J. Verstuyft, R. B. Winters, and D. Albee. 1990. Atherosclerosis susceptibility differences among progenitors of recombinant inbred strains of mice. Atherosclerosis. 110:316-323.

43. de Ritis, F., L. Cacciatore, and G. Ruggierio. 1969. Glutamic oxaloacetic and glutamic pyruvic transaminase of bile in different conditions of experimenta hepatic pathology. Enzymol. Biol. Clin. 10:281-292.

44. Mehrabian, M., L. L. Demer, and A. J. Lusis. 1991. Differential accumulation of intimal monocyte-macrophage relative to lipoproteins and lipofuscin corresponds to hemodynamic forces on cardiac valves in mice. Arterioscler. Thromb. 11:947-957.

45. Parhami, F., Z. T. Fang, A. M. Fogelman, A. Andalibi, M. C. Territo, and J. A. Berliner. 1993. Minimally modified low density lipoprotein-induced inflammatory responses in endothelial cells are mediated by cAMP. J. Clin. Invest. In press.

46. Rubin, E. M., R. M. Krauss, E. A. Spangler, J. G. Verstuyft, and S. M. Clift. 1991. Inhibition of early atherogenesis in transgenic mice by human apolipoprotein AI. Nature (Lond.). 353:265-267.

47. Lakatos, J., and A. Harsagyi. 1988. Serum total, HDL, LDL cholesterol and triglyceride levels in patient with rheumatoid arthritis. Clin. Biochem. 21:9396.

48. Monson, R. R., and A. P. Hall. 1976. Mortality among arthritics. $J$. Chronic Dis. 29:459-467.

49. Koota, K., H. Isomaki, and O. Mutru. 1977. Death rate and causes of death in RA patients during a period of five years. Scand. J. Rheumatol. 6:241244. 